VITA 

Life in a Zone of Social Abandonment

\section{João Biehl}

Photographs by Torben Eskerod

Updated with a New Afterword

and Photo Essay

따

University of California Press

Berkeley Los Angeles London 
University of California Press, one of the most distinguished university presses in the United States, enriches lives around the world by advancing scholarship in the humanities, social sciences, and natural sciences. Its activities are supported by the UC Press Foundation and by philanthropic contributions from individuals and institutions. For more information, visit www.ucpress.edu.

University of California Press

Berkeley and Los Angeles, California

University of California Press, Ltd.

London, England

(C) 2005, 2013 by The Regents of the University of California

ISBN $978-0-520-27295-8$

The Library of Congress has cataloged an earlier edition of this book as follows:

Library of Congress Cataloging-in-Publication Data

Biehl, João Guilherme.

Vita : life in a zone of social abandonment/João Biehl; photographs by Torben Eskerod.

p. $\mathrm{cm}$.

Includes bibliographical references and index.

ISBN 978-0-520-24278-4 (pbk. : alk. paper)

I. Vita (Asylum : Porto Alegre, Brazil) 2. Institutional care-Brazil-Porto Alegre. 3. Marginality, SocialBrazil-Porto Alegre. I. Title.

HV63.B6B 542005

$3^{62^{\prime} .0425^{\prime} \circ 9815-\mathrm{dc} 22}$

2005041745

Manufactured in the United States of America
$\begin{array}{llllllllll}22 & 21 & 20 & 19 & 18 & 17 & 16 & I_{5} & 14 & 13\end{array}$
I0 $\quad 9 \begin{array}{lllllllll} & 8 & 7 & 6 & 5 & 4 & 3 & 2 & \text { I }\end{array}$

The paper used in this publication meets the minimum requirements of ANSI/NISO Z39.48-1992 (R 2002)

(Permanence of Paper). 
For Adriana and Andre 
